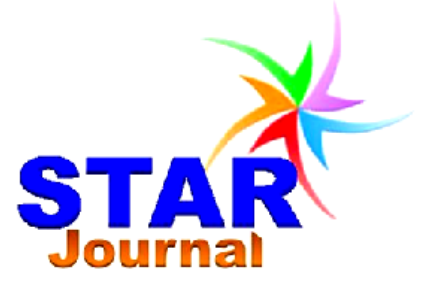

ISSN: 2226-7522(Print) and 2305-3327 (Online) Science, Technology and Arts Research Journal April-June 2012, 1(2):01-11 www.starjournal.org

Copyright@2012 STAR. All Rights Reserved

Original Research

\title{
Participatory Barley Variety Selection and Farmers' Selection Criteria in the Bale Highlands of Southeastern Ethiopia
}

\author{
Zerihun $\mathrm{J}^{1 *}$, Amsalu $\mathrm{A}^{2}$, and Grando $\mathrm{S}^{3}$ \\ ${ }^{1}$ Department of Plant Science, College of Agriculture and Natural Resources, Wollega University, \\ Post Box No: 692, Nekemte, Ethiopia \\ ${ }^{2}$ Department of Crop Research, Oromia Agricultural Research Institute, Addis Ababa, Ethiopia \\ ${ }^{3}$ The International Center for Agricultural Research in the Dry Areas (ICARDA), Global Barley \\ Improvement Program. Post Box No: 5466, Aleppo, Syria
}

\begin{tabular}{|c|c|}
\hline Abstract & Article Information \\
\hline The aim of the study was to identify farmers' selection criteria, preferences and & Received : 06-02-2012 \\
\hline Southeastern part of Ethiopia. The experiment was conducted in non-replicated & Revised : 20-06-2012 \\
\hline plots at each location on plot size of $16 \mathrm{~m}^{2}$ in 2007 Bona and on $25 \mathrm{~m}^{2}$ in 2008 & Accepted : 25-06-2012 \\
\hline $\begin{array}{l}\text { Ganna and Bona cropping seasons. Yleld data was taken in } \mathrm{kg} \text { plot and converted } \\
\text { in to } \mathrm{th}^{-1} \text {.Selection criteria was set together with farmers; and ranked by farmers }\end{array}$ & Keywords: \\
\hline and breeders. Farmers and breeders made visual score of each plot on 1-5 scale & Barley \\
\hline recording problem. The result showed that grain yield, disease resistance, effective & Participatory \\
\hline tillers, early maturity and kernel size (plumpness) were among the most important & Variety Selection \\
\hline variety with insect and disease resistant and early maturing types. And farmers & Criteria \\
\hline were able to identify the higher yielding barley varieties as breeders. Varieties such & Preferences \\
\hline most of the local farmers across locations except at Hora Soba (Upper Dinsho) & ${ }^{\star}$ Corresponding Author: \\
\hline site. Shage, Dimtu varieties and $27^{\text {th }}$ IBON $73 / 99$ (semi-dwarf advanced line) were & Zerihun Jalata \\
\hline $\begin{array}{l}\text { preferred by the Hora Soba local farmers. Thus, attention should be given to seed } \\
\text { multiplication and dissemination of barley varieties which have been highly } \\
\text { preferred by the local farmers. It is important to consider farmers preferences in } \\
\text { crop improvement to improve the adoption of agricultural technologies which } \\
\text { ultimately have significant contribution in production and productivity. }\end{array}$ & E-mail: jaluu_z@yahoo.com \\
\hline
\end{tabular}

\section{INTRODUCTION}

Barley (Hordeum vulgare L.) is one of the most important staple food crops in the highlands of Ethiopia (CSA, 2005) and its grain accounts for over $60 \%$ of the food of the people in the high lands of Ethiopia, for whom barley is one of the main sources of calories (ICARDA, 2002). It ranks fourth among the cereals in worldwide production (Kling and Hayes, 2004) and fifth in Ethiopia with national average of about 12 quintal per hectare (CSA, 2005). It is used as human food, livestock feed and for malting purposes (Harlan, 1976; Onwueme and Singh, 1991; Kling and Hayes, 2004). In Ethiopia, barley production is mainly constrained by lack of improved varieties, disease and insect pest problem, weed competition and poor soil fertility (Berhane et al., 1996).

Even though many improved barley varieties have been released nationally and regionally from different agricultural research centers in Ethiopia, the national productivity of barley crop did not exceed an average of 12 quintals per hectare for long time. One of the reasons could be adoption rate of improved varieties is very low among small scale farmers including Bale 
Zerihun, Amsalu \& Grando

farmers. Because many breeding strategies follow conventional methods to develop cultivars. And farmers' preferences and criteria would differ from breeders' assumptions. As a result, farmers are reluctant in adopting the new technologies. Less adoption of the varieties may be also due to varieties were not adapted to the cropping systems, the biotic and abiotic stress in the area, the color, taste of produce did not match to the requirement of the consumers or other forms of uses (Voss, 1996). Thus, there should be some mechanisms in which farmers can be involved in crop improvement programs known as participatory approach. Participatory variety selection (PVS) involves the selection of released cultivars and varieties in advanced stages of testing from plant breeding programs and is used to differentiate materials that can be adopted rapidly (Witcombe and Joshi, 1996). Participatory breeding combined with decentralized selection has advantages of meeting their diverse needs by diversified varieties in order to manage risk and satisfy different end uses (Voss, 1996). Decentralized selection enable breeder to utilize farmers knowledge of the crop and the environment to fit crops to the specific needs and uses of farmers (Ceccarrelli et al., 2000). Participatory barley breeding (PBB) has been conducted in Eritrea (ICARDA, 1999), in Morocco (ICARDA, 1998), in Syria (Ceccarrelli et al., 2000) and in Egypt (ICARDA, 2000).

Bale highlands in the South-Eastern part of Ethiopia is a major barley producing areas in Ethiopia and barley is the second most important staple crop next to wheat in area coverage and production (EASE, 2002). Most of improved varieties released nationally did not perform well to these specific areas because of severe shoot fly damage and the late maturity of these varieties has not been preferred by the local farmers. The recently released varieties from Sinana agricultural research center barley breeding program have shown specific adaptation to these environments. However, farmers' preference of the varieties has not been identified well for scaling up and/or out program. Therefore, the present study was designed to identifying farmers' selection criteria, preferences and perceptions of barley crop in Bale highlands; identifying improved varieties which can be easily adopted by the local farmers and indicate better strategies to promote barley technologies in the area. On top of this, the purpose of this study was to generate baseline information about the importance of participatory barley breeding in Bale highlands for future barley breeding programs.
Sci. Technol. Arts Res. J., April-June 2012, 1(2):01-11

\section{MATERIALS AND METHODS}

The experiment was conducted in 2007 in Bona and in 2008 in Ganna by dividing in to two phases:

Phase I: Study was Conducted in 2007 in Bona (July to December) growing season at five representative sites in two districts, namely Sinana (Salka Oda, Salka Urane, Jafara) and Agarfa (Ilani and Rataba) (Table 1). During $1^{\text {st }}$ phase, a total of 12 food and malting barley varieties (Figure 1) were planted on $16 \mathrm{~m}^{2}$ nonreplicated plots with seed and fertilizer rate of 125 $\mathrm{kg} \mathrm{ha}^{-1}$ and $50 \mathrm{~kg}$ per hectare $\left(\mathrm{ha}^{-1}\right)$ of DAP (Diammonium phosphate), respectively, at all sites .

Phase II: Study was conducted during 2008 Ganna (March to July) and cropping seasons at ten representative sites in four districts. These districts (Table 1) includes Sinana (Sinana (on station), Salka Oda, Hisu, Jafara and Robe sites), Lower Dinsho (Homa and Walta'i sites), Upper Dinsho (Hora Sobae site) and Adaba (Adaba (at on station) and Ejersa Chumulugo sites) covering most of representative barley growing areas. Except the Hora Soba (typical cool highland), Homa and Walta'i sites and the other sites represent mid highlands (2300-2500 meter above sea level) with relatively similar topography (Table 1). And except Upper Dinsho and Adaba districts, at all sites varieties were planted during Ganna 2008 cropping season. During phase-II, sixteen barley varieties (Figure 2) including one local and one new food barley candidate variety have been planted at each site on plot size of $25 \mathrm{~m}^{2}$ and with similar seed and fertilizer rate to phase I. Most of the barley varieties used for evaluation was brought from different Agricultural research centers in Ethiopia.

\section{Area Description and Cropping Seasons}

Highlands of Bale is found in the South-East of Addis Ababa in the Bale zone. The experiment was conducted at sites/locations where most of barley research experiments have been conducted by Sinana barley breeding program. These experimental sites cover an altitudinal range of about 2300-3200 m.a.s.l (Table 1). The districts are characterized by bimodal (Sinana, Agarfa, Lower Dinsho) and monomodial (Upper Dinsho and Adaba) rainfall. Accordingly, there are two cropping seasons in the area: Ganna (March to July) and Bona (July to December) seasons. The average rainfall is about $590 \mathrm{~mm}$ in the Ganna and $560 \mathrm{~mm}$ in Bona season (Hailu et al., 1996). 
Table 1: Some physical and biological characteristics of the growing environments in Bale.

\begin{tabular}{|c|c|c|c|c|c|}
\hline District & Site & $\begin{array}{l}\text { Altitude } \\
\text { (m.a.s.I) }\end{array}$ & $\begin{array}{c}\text { Rain Fall } \\
\text { Type }\end{array}$ & $\begin{array}{l}\text { Shoot Fly } \\
\text { Incidence }\end{array}$ & $\begin{array}{c}\text { Cropping } \\
\text { Season Planted }\end{array}$ \\
\hline Sinana & $\begin{array}{l}\text { Sinana } \\
\text { (on station) }\end{array}$ & 2400 & Bimodal & Present & 2008 Ganna \\
\hline Sinana & Salka-Oda & 2400 & Bimodal & Present & $\begin{array}{l}2007 \text { Bona \& } \\
2008 \text { Ganna }\end{array}$ \\
\hline Sinana & Salka-Urane & 2400 & Bimodal & Present & 2007 Bona \\
\hline Sinana & Jafara & 2400 & Bimodal & Present & $\begin{array}{l}2007 \text { Bona \& } \\
2008 \text { Ganna }\end{array}$ \\
\hline Sinana & Hisu & 2400 & Bimodal & Present & 2008 Ganna \\
\hline Sinana & Robe & 2400 & Bimodal & Present & 2008 Ganna \\
\hline Agarfa & Ilani & 2300 & Bimodal & Present & 2007 Bona \\
\hline Agarfa & Rataba & 2400 & Bimodal & Present & 2007 Bona \\
\hline Lower Dinsho & Homa & 2640 & Bimodal & Less & 2008 Ganna \\
\hline Lower Dinsho & Walta'i & 2500 & Bimodal & Less & 2008 Ganna \\
\hline Upper Dinsho & Hora Soba & 3200 & Monomodal & Very minimum & 2008 Ganna \\
\hline Adaba & $\begin{array}{c}\text { Ejersa } \\
\text { Chumulugo }\end{array}$ & 2500 & Monomodal & Very minimum & 2008 Ganna \\
\hline Adaba & $\begin{array}{c}\text { Adaba } \\
\text { (on station) }\end{array}$ & 2500 & Monomodal & Very minimum & 2008 Ganna \\
\hline
\end{tabular}

Cultural Practices, Data Collection and Statistical Analysis

The local farmers and breeders were participated in the selection process. Selection criteria were set jointly with farmers. Farmers and breeders made selection separately and/or in group. In addition to breeders', agronomists, pathologists, entomologists and extensionists have been also involved in evaluation. Visual scoring of the plots or varieties was taken based on the (1-5) scale by the farmers and breeders. Where, $1=$ very good, 2=good, 3=average, 4=poor and 5 =indicating very poor. Farmers were supported by our technical staff in recording the data during scoring or ranking. Grain yield data was recorded for each plot. Other recommended agronomic and cultural practices have been applied uniformly. Evaluation and variety selection was done at maturity period. Statistical analysis was done by using statistical package for social science (SPSS) version 12.0, 2003 software program.

\section{RESULTS AND DISCUSSION}

Technology transfer is a very problematic in developing countries and sometimes new technologies developed by researchers may not be adopted by the farmers. This is due to the limitations of formal plant breeding which is related to their inability to address the enormous diversity of environmental conditions and endusers' needs (Morris and Bellon, 2004; Ceccarrelli and Grando, 2005). It concentrate on increasing yield potential in favorable environments through application of high inputs and give less attention to the importance of adaptation to variable and risky low input rain fed conditions, secondary crop uses and cultural preferences (de Boef and Ogliari, 2008). Hence, participatory approach ensures the involvement of farmers in crop improvement programs to alleviate problems related to technology transfer or adoption and integrate farmers' indigenous knowledge in crop improvement.

Hence, participatory barley variety selection which was conducted during phase I was at five sites in two districts (Sinana and Agarfa) during 2007. Bona cropping season; whereas during experimental phase II (Ganna and Bona during 2008), the research was carried out at ten representative sites in four districts (Sinana, Lower Dinsho, Upper Dinsho and Adaba) of Bale highlands. The overall research report of this research work has been presented as follows: 


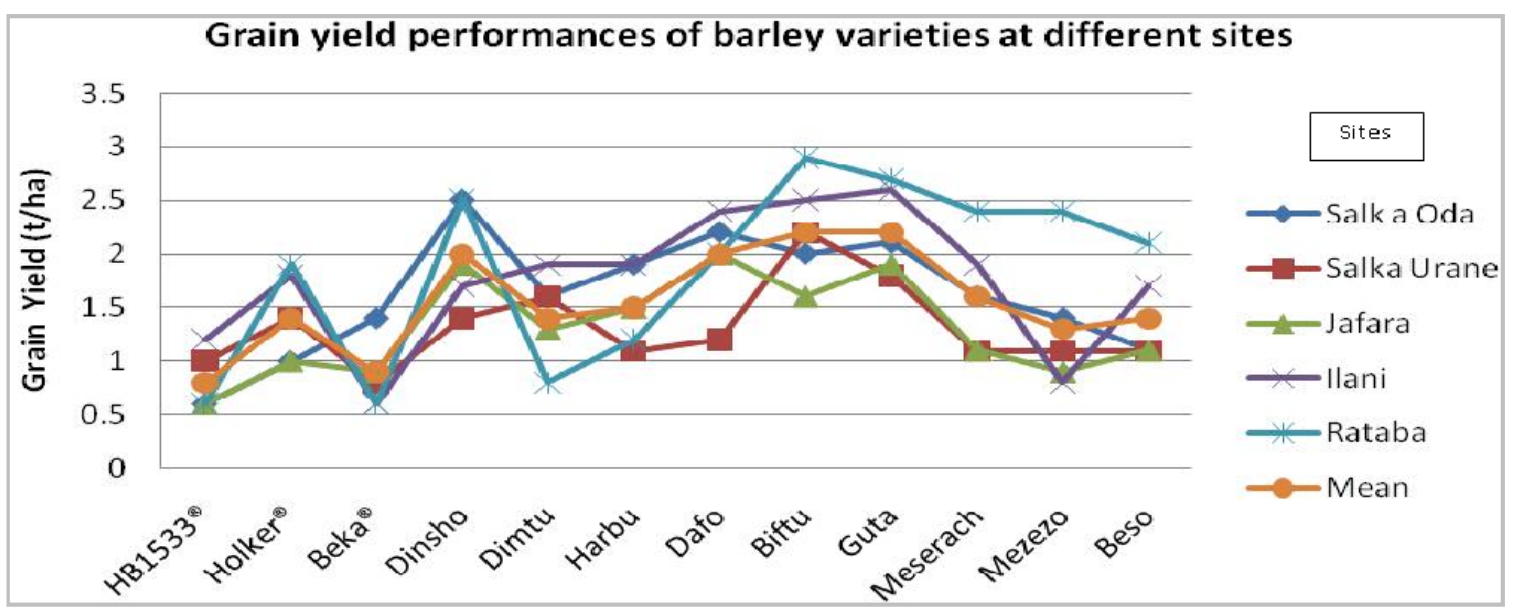

Figure 1: Grain yield in tons per hectare of barley varieties at five sites in Bale highlands during 2007 (Phase I) Bona season.

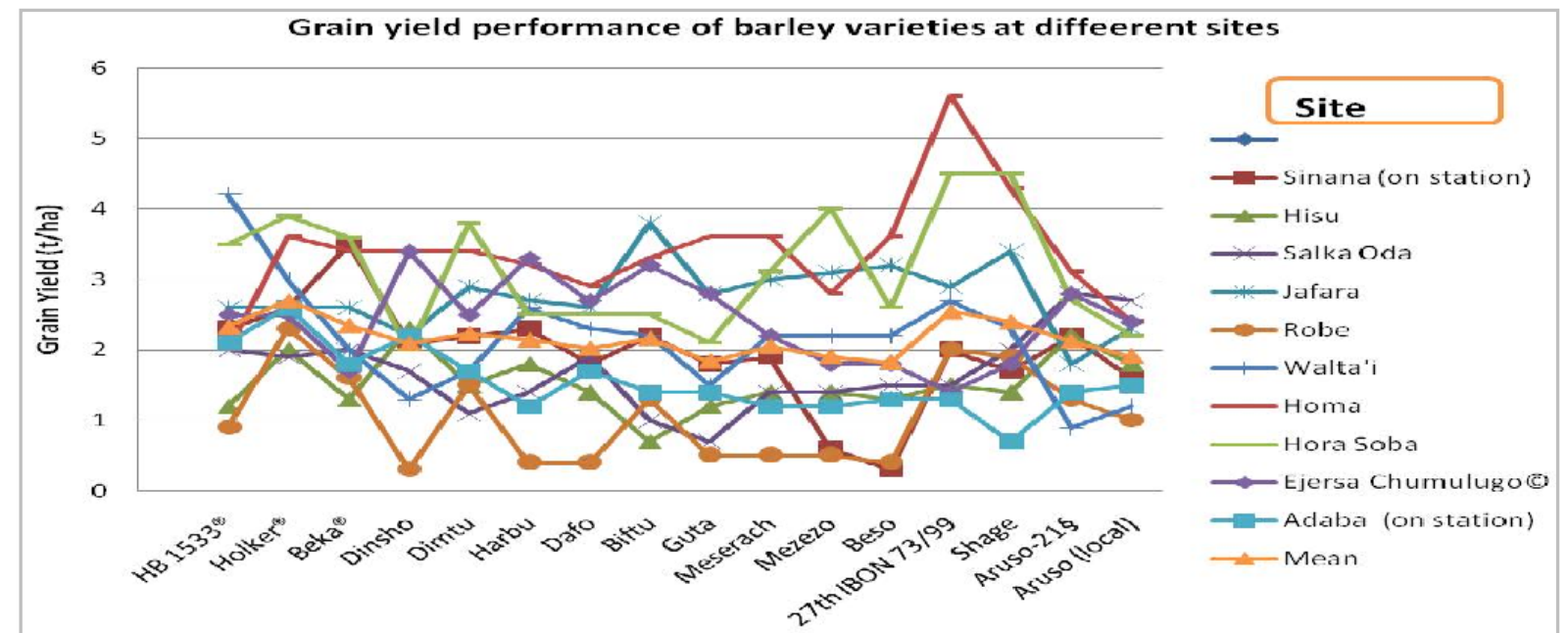

Figure 2: Grain yield tons per hectare of barley varieties tested at ten sites in Bale highlands during 2008 (Phase II) Ganna and Bona season.

\section{Phase I: Participatory Research}

\section{Selection Criteria}

Farmers and breeders rankings of selection criteria, visual scoring and variety ranking is presented in Table (2, 3, 4 and 5), respectively. A range of 7 to 10 farmers have been participated at individual site. Selection criteria ranked by individual farmers varied depending on their priority and preference. Grain yield was the first selection criteria of farmers at all sites except Salka Urane site in which drought and insect resistance was the top priority of selection. Disease resistance, early maturity and drought resistance were the most important selection criteria used by the farmers next to grain yield (Table 2). It was observed that during selection, farmers were observed opening apart the plants in order to see visually some important traits, for instance productive tillers and disease resistance. Thus, grain yield, disease resistance, early maturity and drought resistance were among the most important selection criteria used by farmers at most of the sites. On the other hand, breeders also participated in the rankings of selection criteria. Accordingly, almost at all sites grain yield was ranked first followed by biotic stresses such as insect resistance and disease resistance which are prevalent in the areas as a yield reducing factors (Table 2 ). Beside this, farmers and breeders have also ranked selection criteria jointly together at all sites so that early maturity, grain yield, disease resistance, insect resistance and utilization were selected by the group as important criteria at all sites (data not shown).

\section{Visual Score}

Visual score of the plots or varieties have been carried out before variety selection by farmers and breeders separately at all sites to score overall performance of the varieties (Table 3). Except at Rataba site, most of the farmers gave 


\section{Zerihun, Amsalu \& Grando}

very good score for Guta variety at all sites. During scoring, farmers gave better value or performance for early maturing with productive tillers and disease resistant varieties. Whereas, majority of the farmers gave poor to very poor scores for late types regardless of their better performance in the field. Breeders gave very good score to Guta except at Salka Urane.

\section{Variety Selection}

In the ranking of best varieties, most farmers selected Guta as first choice in individual and/or in team at all sites except at Jafara in which the group selected as second (Table 4). This variety was early maturing, relatively free of diseases, with productive tillers and have plump seed as described by the local farmers during selection. At Ilani site, Guta variety was preferred by some farmers for injera (thin leavened bread), Beso (moistened flour) and tella (local drink). The second and third ranking variety varied among individual farmers and/or in group at different sites. For instance, one farmer at Salka Oda selected Beso variety differently for Beso (moistened flour). Meserach variety was also preferred for injera by some Salka Oda farmers, and as lodging resistant by Salka Oda, Jafara and Ilani farmers as a result of its medium height and uniformity. Though Biftu variety has uniform, good stand, large straw, looking weed competent and good spike, some farmers were suggesting it to give less grain weight as compared to similar volume of the first selected variety Guta. That means, it yield less flour amount and has large husk content. In addition, it has medium maturity and less productive tillers as suggested by the farmers. Most of the farmers considered Mezezo and Beso variety as new variety because the varieties have black seed color which is different from their local variety or not commonly produced in the area.

Breeders selected Guta, Biftu, and Meserach as first, second and third ranking varieties, respectively at most of the sites in Bale mid highlands (Table 5). The variety called Biftu was selected by breeders individually and/or in group next to Guta at Jafara, Salka Urane and Salka Oda sites. Concerning yielding potential of the varieties, varieties such as Dinsho, Dafo, Guta and Biftu have shown relatively better grain yield performance at most of the locations or sites. All the selected varieties were developed from landraces. Generally, the overall mean grain yield indicates that Biftu (2.2 tons per hectare), Guta (2.2 tons per hectare), Dinsho (2.0 tons per hectare) and Dafo (2.0 tons per hectare) were better yielding varieties over locations (Figure 1).
Sci. Technol. Arts Res. J., April-June 2012, 1(2):01-11

\section{Phase II: Participatory Research}

\section{Selection Criteria}

A total of 89 farmers have been participated in participatory variety selection at ten sites ranging from 4-14 farmers per site during 2008 Ganna and Bona cropping seasons. Farmers and breeders have ranked their selection criteria at each site (data not shown). The top priority of farmers' selection criteria varied from site to site. Hence, grain yield was ranked as the first selection criteria by Sinana (on station) and Hisu farmers. Similarly, early maturity was the top ranking criteria by Waltai and Chumulugo farmers.

Salka Oda and Jafara farmers considered disease resistance as the first important criteria than yield. Grain yield, disease resistance and early maturity were selected as second important criteria at least at two locations or sites. On the other hand, effective tillering was the top priority of selection among Upper Dinsho farmers. Generally, grain yield, disease resistance, early maturity and effective tillers were the most important farmers' selection criteria at these sites. While, breeders selected grain yield as the first top ranking criteria at all sites or locations. While, disease resistance and early maturity was selected as second priority at most of the evaluation sites.

Visual Scoring of Varieties: Visual scoring of the varieties was done by farmers and breeders separately to see the general performance of the varieties (Table 6). Accordingly, farmers generally scored good to very good performance for Aruso/EH956/F ${ }_{2}-8 \mathrm{H}-6-4-S N R F B C 99 G 003-21$ ' candidate variety whereas breeders scoring of varieties differed from sites to site. The local variety has not shown visually better performance at most of the sites. Homa site was an area where most of the varieties have shown good performances than any site may be because of its location which is about in between the other locations.

Variety Selection: Farmers and breeders made selection of varieties in the field based on their criteria (Table 7) at each site during 2008 Ganna and Bona cropping season. In individual farmers' ranking of best varieties, farmers' selected Aruso/EH956/F ${ }_{2}-8 \mathrm{H}-6-4-S N R F B C 99 G 003-21$, new candidate variety as a $1^{\text {st }}$ top ranking variety at Salka Oda, Hisu, Jafara and Adaba (On station) and this variety was also selected as $2^{\text {nd }}$ and $3^{\text {rd }}$ ranking variety at least at one site. According to farmers' opinion, this variety has 
Zerihun, Amsalu \& Grando

Sci. Technol. Arts Res. J., April-June 2012, 1(2):01-11

Table 2: Mean of selection criteria ranked by individual farmers and breeders at five sites in Bale highlands during 2007 Bona season.

\begin{tabular}{|c|c|c|c|c|c|c|c|c|c|c|}
\hline \multirow[b]{2}{*}{ District } & \multirow[b]{2}{*}{ Site } & \multirow[b]{2}{*}{ Participant } & \multicolumn{8}{|c|}{ Selection Criteria } \\
\hline & & & $\begin{array}{l}\text { Grain } \\
\text { Yield }\end{array}$ & Straw & spike & Utilization & Maturity & $\begin{array}{c}\text { Disease } \\
\text { Resistance }\end{array}$ & $\begin{array}{c}\text { Drought } \\
\text { resistance }\end{array}$ & $\begin{array}{c}\text { Insect } \\
\text { resistance }\end{array}$ \\
\hline \multirow{6}{*}{ Sinana } & \multirow[t]{2}{*}{ Jafara } & Farmers & 1.6 & 6.8 & 7.3 & 6.0 & 3.6 & 4.4 & 2.6 & 3.8 \\
\hline & & Breeders & 1.3 & 7.8 & 6.8 & 4.3 & 4.3 & 4.3 & 4.8 & 3.3 \\
\hline & \multirow{2}{*}{$\begin{array}{l}\text { Salka } \\
\text { Urane }\end{array}$} & Farmers & 4.0 & 7.0 & 7.0 & 5.0 & 4.0 & 5.0 & 2.0 & 2.0 \\
\hline & & Breeders & 1.0 & 8.0 & 6.5 & 4.8 & 4.5 & 3.8 & 4.5 & 3.0 \\
\hline & \multirow{2}{*}{$\begin{array}{l}\text { Salka } \\
\text { Oda }\end{array}$} & Farmers & 2.1 & 6.6 & 6.4 & 5.6 & 3.7 & 2.7 & 4.7 & 3.9 \\
\hline & & Breeders & 1.0 & 8.0 & 6.5 & 4.5 & 4.8 & 3.3 & 5.0 & 3.0 \\
\hline \multirow{4}{*}{ Agarfa } & \multirow[t]{2}{*}{ Ilani } & Farmers & 1.6 & 8.0 & 7.1 & 4.6 & 5.0 & 5.0 & 5.7 & 4.0 \\
\hline & & Breeders & 1.0 & 8.0 & 6.5 & 4.5 & 4.8 & 3.3 & 5.0 & 3.0 \\
\hline & \multirow[t]{2}{*}{ Rataba } & Farmers & 1.1 & 7.9 & 7.0 & 5.3 & 5.0 & 3.7 & 5.3 & 5.9 \\
\hline & & Breeders & 1.0 & 8.8 & 8.3 & 5.3 & 5.0 & 4.0 & 6.3 & 2.3 \\
\hline
\end{tabular}

Table 3: Visual score of varieties by farmers and breeders at five sites in Bale highlands during 2007 Bona season.

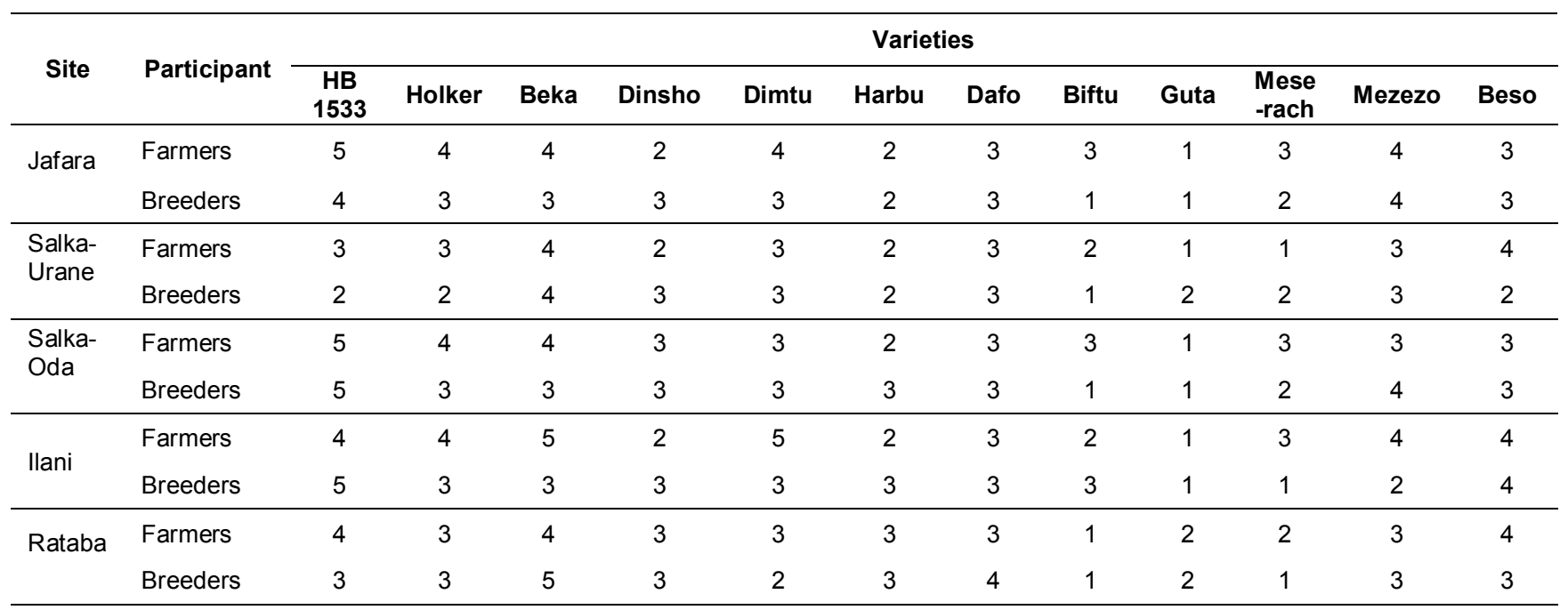

Table 4: Farmers' rankings of better barley varieties at five sites in Bale high lands during 2007 Bona season.

\begin{tabular}{ccccccc}
\hline & & \multicolumn{5}{c}{ Evaluation Sites } \\
\cline { 3 - 7 } No. & Variety & Jafara & Salka Urane & Salka Oda & Ilani & Rataba \\
\hline 1 & Guta & $1\left(2^{\star}\right)$ & $1\left(1^{*}\right)$ & $1\left(1^{*}\right)$ & $1\left(1^{*}\right)$ & 1 \\
2 & Dinsho & $2\left(1^{*}\right)$ & $3\left(2^{*}\right)$ & - & $3\left(2^{*}\right)$ & 4 \\
3 & Biftu & 3 & 4 & 4 & $2\left(3^{*}\right)$ & 2 \\
4 & Harbu & 4 & 2 & $2\left(2^{*}\right)$ & $4\left(4^{*}\right)$ & 3 \\
5 & Dafo & $\left(3^{\star}\right)$ & $5\left(3^{\star}\right)$ & 3 & - & - \\
6 & Meserach & - & - & $-\left(3^{*}\right)$ & - & 4 \\
\hline
\end{tabular}

*Indicate the rank given by farmers in group 
Table 5: Breeders' ranking of better barley varieties at five sites in Bale high lands during 2007 Bona season.

\begin{tabular}{ccccccc}
\hline & & \multicolumn{5}{c}{ Evaluation Sites } \\
\cline { 3 - 7 } No & Variety & Jafara & Salka-Urane & Salka-Oda & Ilani & Rataba \\
\hline 1 & Guta & $1\left(1^{*}\right)$ & 1 & $1\left(1^{*}\right)$ & $2\left(2^{*}\right)$ & 3 \\
2 & Biftu & $2\left(2^{*}\right)$ & 2 & $2\left(2^{*}\right)$ & $1\left(1^{*}\right)$ & 1 \\
3 & Meserach & $3\left(3^{*}\right)$ & 3 & $3\left(3^{*}\right)$ & $3\left(3^{*}\right)$ & 2 \\
\hline
\end{tabular}

Table 6: Visual scoring (1-5) of barley varieties by the farmers and breeders at different sites in Bale highlands during 2008 Ganna and Bona cropping season.

\begin{tabular}{|c|c|c|c|c|c|c|c|c|c|c|c|c|c|c|c|c|c|}
\hline $\begin{array}{c}\text { Site/ } \\
\text { Variety }\end{array}$ & 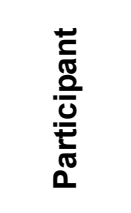 & 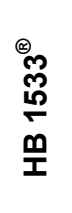 & $\begin{array}{l}\stackrel{\infty}{\frac{1}{d}} \\
\frac{\dot{y}}{\overline{0}} \\
\frac{1}{1}\end{array}$ & 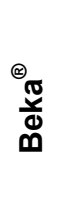 & $\begin{array}{l}\frac{0}{a} \\
\frac{c}{0} \\
\frac{c}{0}\end{array}$ & $\begin{array}{l}\text { ग् } \\
\text { है }\end{array}$ & $\begin{array}{l}\bar{\Xi} \\
\frac{0}{\frac{1}{\pi}} \\
\text { I }\end{array}$ & $\frac{\stackrel{0}{\pi}}{\stackrel{\pi}{0}}$ & $\frac{P}{\underline{m}}$ & $\underset{0}{\stackrel{\pi}{J}}$ & 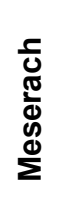 & $\begin{array}{l}\stackrel{0}{N} \\
\mathbb{N} \\
\mathbb{N}\end{array}$ & \& & 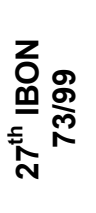 & $\begin{array}{l}\text { D্ } \\
\text { ๘ } \\
\frac{\pi}{\omega}\end{array}$ & 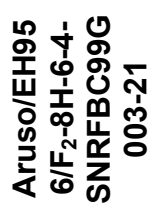 & 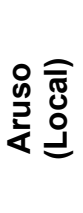 \\
\hline $\begin{array}{c}\text { Sinana } \\
\text { (on Station) }\end{array}$ & Farmers & 2.8 & 3.2 & 3.8 & 2.8 & 2.5 & 2.3 & 3.2 & 2.0 & 3.0 & 3.3 & 4.0 & 3.8 & 2.8 & 2.5 & 2.7 & 4.3 \\
\hline \multirow{2}{*}{ Salka Oda } & Farmers & 1.7 & 2.9 & 2.9 & 2.6 & 3.7 & 3.1 & 3.3 & 3.7 & 3.0 & 2.0 & 3.0 & 2.7 & 2.9 & 3.3 & 1.3 & 2.4 \\
\hline & Breeder & 3.0 & 3.0 & 3.0 & 3.0 & 3.0 & 3.0 & 3.0 & 3.0 & 3.0 & 2.0 & 3.0 & 3.0 & 3.0 & 3.0 & 1.0 & 3.0 \\
\hline \multirow{2}{*}{ Hisu } & Farmers & 3.7 & 2.9 & 2.3 & 1.5 & 3.8 & 2.3 & 2.8 & 3.4 & 2.6 & 2.4 & 3.4 & 2.9 & 3.3 & 2.4 & 1.8 & 2.0 \\
\hline & Breeder & 4.0 & 3.0 & 3.0 & 3.0 & 3.0 & 2.0 & 3.0 & 4.0 & 4.0 & 3.0 & 3.0 & 3.0 & 3.0 & 2.0 & 2.0 & 3.0 \\
\hline \multirow{2}{*}{ Jafara } & Farmers & 2.5 & 2.1 & 2.5 & 2.3 & 2.0 & 2.0 & 2.8 & 2.4 & 1.0 & 2.3 & 2.4 & 2.8 & 2.4 & 2.4 & 1.6 & 1.9 \\
\hline & Breeder & 3.0 & 3.0 & 3.0 & 4.0 & 2.0 & 1.0 & 3.0 & 1.0 & 3.0 & 2.0 & 3.0 & 3.0 & 2.0 & 2.0 & 2.0 & 3.0 \\
\hline Homa & Breeder & 1.0 & 2.0 & 2.0 & 4.0 & 2.0 & 1.0 & 3.0 & 1.0 & 1.0 & 1.0 & 2.0 & 2.0 & 2.0 & 3.0 & 1.0 & 2.0 \\
\hline \multirow{2}{*}{ Walta'i } & Farmers & 3.0 & 1.0 & 4.0 & 4.0 & 1.0 & 4.0 & 4.0 & 1.0 & 4.0 & 1.0 & 1.0 & 1.0 & 1.0 & 3.0 & 2.0 & 4.0 \\
\hline & Breeder & 1.0 & 2.0 & 2.0 & 3.0 & 1.0 & 1.0 & 2.0 & 1.0 & 2.0 & 1.0 & 1.0 & 2.0 & 2.0 & 2.0 & 1.0 & 3.0 \\
\hline \multirow{2}{*}{ Hora Soba } & Farmers & 4.0 & 4.0 & 4.0 & 4.0 & 1.0 & 3.0 & 5.0 & 3.0 & 4.0 & 1.0 & 3.0 & 3.0 & 1.0 & 1.0 & 3.0 & 4.0 \\
\hline & Breeder & 3.0 & 2.0 & 4.0 & 4.0 & 1.0 & 3.0 & 5.0 & 3.0 & 3.0 & 1.0 & 3.0 & 3.0 & 1.0 & 2.0 & 3.0 & 4.0 \\
\hline \multirow{2}{*}{$\begin{array}{c}\text { Ejersa } \\
\text { Chumulugo }\end{array}$} & Farmers & 2.2 & 2 & 3.6 & 2 & 2.4 & 3 & 3.4 & 2.2 & 2.8 & 1.8 & 2.4 & 3.0 & 3.0 & 2.6 & 1.8 & 3.2 \\
\hline & Breeder & 3.0 & 3.0 & 4.0 & 3.0 & 1.0 & 3.0 & 4.0 & 3.0 & 4.0 & 1.0 & 2.0 & 3.0 & 3.0 & 3.0 & 3.0 & 5.0 \\
\hline
\end{tabular}

additional merits such as earliness, better adapted to the environment, lodging tolerant and effective tillering. Generally, Biftu, Dafo, Guta, Meserach varieties and $27^{\text {th }}$ IBON 73/99 advanced line have been selected as the first priority at least at one site. Other varieties such as Beso, Mezezo, Dimtu, Shage and Harbu have been the choice of farmers at some sites as a second and/or third ranking. On the other hand, though selection varied from site to site, breeders also ranked best performing varieties. Thus, Harbu, Aruso/EH956/F $2-8 H-6-4-S N R F B C 99 G 003$ -21 , Biftu, $27^{\text {th }}$ IBON 73/99 (advanced line) and Meserach have been their first choices at least at one site. In addition, these varieties have been also frequently selected as second and/or third rank at most sites. In general, there is an overlap of choice between farmers and breeders variety selection at most sites.

In group selection, except at Ejersa Chumulugo, Sinana (on station) and Hora Soba sites, all farmers ranked Aruso/EH956/F $2-8 \mathrm{H}-6-4-$ SNRFBC99G003-21 candidate variety as the first best preferred variety. Guta, Harbu and Biftu were the second and/or third farmers' choice at least at two sites. On the other hand, the late maturing varieties such as Shage, Dimtu and $27^{\text {th }}$ 


\section{Zerihun, Amsalu \& Grando}

IBON 73/99 have been selected only at Hora Soba site (Upper Dinsho) during farmers' individual and/or group selection where they are well adapted and have shown superior performance than other sites. Meserach variety was also farmers' choice because of it is relatively early maturing, good stand, lodging tolerant (short), bending its spike (sprout resistant) as explained by farmers. At some sites farmers considered also variety selection based on some specific traits which are not commonly used by others and even difficult to confirm their reasoning. For instance, some farmers preferred Aruso/EH956/F ${ }_{2}-8 \mathrm{H}-6-4-S N R F B C 99 G 003-21$ due to "the nature of shading its awns at maturity (at Jafara site) which is good during pilling up or storing in the field temporarily which makes easy during threshing and cleaning", as farmers explained. At Upper Dinsho (Hora Soba) and Jafara, the local farmers prefer varieties with plump seeds and less husk cover or content (they stated as "hansara baay'e kan hinkabne" in Afan Oromo language, literally meaning 'seeds which does not have large husk content'. Beside this, at Upper Dinsho, some farmers described the variety shage as resistant to bird damage but show resistance to threshing when trampling over
Sci. Technol. Arts Res. J., April-June 2012, 1(2):01-11

by horses or cows. This variety has been distributed to the local farmers some years ago. The number of kernels per spike has been also used as main selection criteria in the selection of varieties at Homa site.

When the varieties selected by farmers' and breeders' are compared with the yield performance data of different sites during 2008 Ganna and Bona cropping season (Figure 2), the varieties selected at most sites by the farmers' and/or breeders have shown good grain yield performance. Even though the grain yield performances of malting barley varieties were good, farmers did not select them except at Walta'i site and the local variety (Aruso) was not selected at any of the sites. During phase I of this research work, the varieties such as Guta, Dinsho, Biftu, Harbu and Dafo were ranked from 1 to 3 by farmers at least at one site indicating similarity in farmers' preference for these varieties (Table 4). Whereas during phase II (Table 7), at all sites except Hora Soba, all these listed varieties except Dinsho variety were still farmers' choice in addition to the new candidate variety developed through crossing at Sinana, Aruso/EH956/F $2-8 H-6-4-S N R F B C 99 G 003-21$.

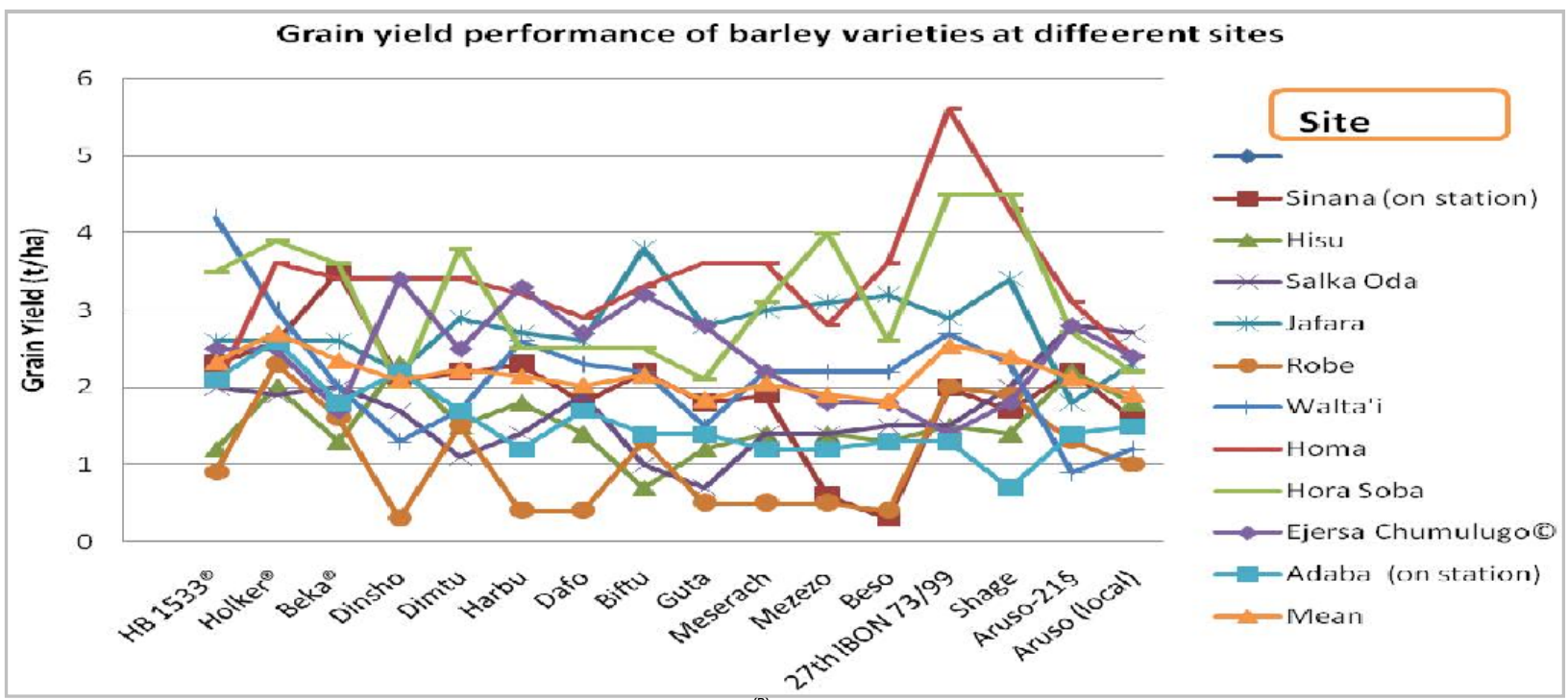

Aruso-21=Aruso/EH956/ $\mathrm{F}_{2}-8 \mathrm{H}-6-4-S N R F B C 99 G 003-21,{ }^{(e)}=$ malting barley variety, (C) At Ejersa Chumulugo site, malting barley varieties HB 1533, Holker and Beka were replaced by $F_{2}(S x S) 237 / 99, F_{2}(S x S) 222 / 99$ and $8^{\text {th }}$ EMBSN 3/99 food barley varieties, respectively.

Figure 2: Grain yield tons per hectare $\left(\mathrm{t} \mathrm{ha}^{-1}\right)$ of barley varieties tested at ten sites in Bale highlands during 2008 Ganna and Bona season, $2^{\text {nd }}$ phase.

In the present study, grain yield, disease resistance, productive or effective tillers, early maturity and kernel plumpness were the most important selection criteria frequently used by the farmers during the two phases. This result agrees with farmers' selection criteria in Morocco at
Merchouch area and Jemma Shahim area in terms of grain yield and earliness, at respective areas. In Tigray Northern part of Ethiopia, farmers were able to select and develop barley variety known as Himblil and Dembay varieties. 
Table 7: Individual farmers and breeders' ranking (1-3) of better barley varieties at ten evaluation sites in Bale high lands during 2008 Ganna and Bona seasons.

\begin{tabular}{|c|c|c|c|c|}
\hline Site & Participant & $1^{\text {st }}$ Ranking & $2^{\text {nd }}$ Ranking & $3^{\text {rd }}$ Ranking \\
\hline \multirow{2}{*}{$\begin{array}{c}\text { Sinana } \\
\text { (on station) }\end{array}$} & Farmers & Biftu & Harbu & Dimtu \\
\hline & Breeder & Harbu & Biftu & $\begin{array}{l}\text { Aruso/EH956/F } 2-8 \mathrm{H}-6- \\
\text { 4-SNRFBC99G003-21 }\end{array}$ \\
\hline \multirow{2}{*}{ Salka Oda } & Farmers & Aruso/EH956/F $2-8 H-6-4-S N R F B C 99 G 003-21$ & Beso & Meserach \\
\hline & Breeder & Aruso/EH956/F $2-8 H-6-4-S N R F B C 99 G 003-21$ & Meserach & Guta \\
\hline \multirow{2}{*}{ Hisu } & Farmers & Aruso/EH956/F2-8H-6-4-SNRFBC99G003-21 & $\begin{array}{c}\text { Meserach, } \\
27^{\text {th }} \text { IBON 73/99@ }\end{array}$ & Biftu \\
\hline & Breeder & Aruso/EH956/F $2-8 H-6-4-S N R F B C 99 G 003-21$ & $27^{\text {th }}$ IBON $73 / 99$ & Shage \\
\hline Robe & Farmers & Aruso/EH956/F $2-8 H-6-4-S N R F B C 99 G 003-21$ & Mezezo & Biftu \\
\hline \multirow{2}{*}{ Jafara } & Farmers & Aruso/EH956/F2-8H-6-4-SNRFBC99G003-21@ & Meserach & Shage \\
\hline & Breeder & Harbu & Biftu & $\begin{array}{l}\text { Aruso/EH956/F } 2-8 \mathrm{H}-6- \\
\text { 4-SNRFBC99G003-21 }\end{array}$ \\
\hline \multirow{2}{*}{ Homa } & Farmers & Dafo & Guta & Biftu \\
\hline & Breeder & Biftu & Harbu & Meserach \\
\hline \multirow{2}{*}{ Walta'i } & Farmers & Holker* & Mezezo & HB1533* \\
\hline & Breeder & Biftu & Meserach & $\begin{array}{l}\text { Aruso/EH956/F } 2-8 H-6- \\
\text { 4-SNRFBC99G003-21 }\end{array}$ \\
\hline \multirow{2}{*}{ Hora Soba } & Farmers & $27^{\text {th }}$ IBON $73 / 99$ & Meserach & Dimtu \\
\hline & Breeder & $27^{\text {th }}$ IBON $73 / 99$ & Meserach & Dimtu \\
\hline \multirow{2}{*}{$\begin{array}{c}\text { Ejersa } \\
\text { Chumulugo }\end{array}$} & Farmers & Meserach & $\begin{array}{l}\text { Aruso/EH956/F } 2-8 \mathrm{H}-6- \\
\text { 4-SNRFBC99G003-21 }\end{array}$ & Guta \\
\hline & Breeder & Meserach & Biftu & $\begin{array}{l}\text { Aruso/EH956/F } 2-8 \mathrm{H}-6- \\
\text { 4-SNRFBC99G003-21 }\end{array}$ \\
\hline \multirow{2}{*}{$\begin{array}{c}\text { Adaba } \\
\text { (on station) }\end{array}$} & Farmers & Aruso/EH956/F2-8H-6-4-SNRFBC99G003-21 & Dimtu & Harbu \\
\hline & Breeder & Aruso/EH956/F $2-8 H-6-4-S N R F B C 99 G 003-21$ & Harbu & Dimtu \\
\hline
\end{tabular}

Especially Himblil showed superior performances under low input conditions. It is more stable than the improved varieties under low input and low rainfall conditions of Tigray (Fetien and Bjørnstad, 2008). During selection of varieties, Bale farmers have used disease resistance as a major factor in their selection which contradicts with farmers' selection criteria in Morocco (ICARDA, 1998) and Eritrea (ICARDA, 1999). But, insect damage (shoot fly damage) is little known to most of the farmers in the area and they consider it as generally adaptation problem of the variety to the climate. Straw yield was given less priority by the local farmers in all sites, may be because of the presence of alternative feed sources mainly from wheat, linseed and maize as opposed to the ICARDA (1998) report in Morocco. Selections in Egypt at El Karamis, El Shawaier, Ghout Rabbah, El Magroun and East Barrani sites showed that farmers' scores were positively and significantly correlated with biomass and grain yield, but breeders gave high (good) scores to tall plants; and in Syria farmers showed strong preferences for barley seed color and row type in such a way that farmers in Tel Brack, Byloun and Melabya areas preferred only two row types with black seeded in contrast farmers in Mardabsi and Suran sites that wanted only two row types with white seed colored (ICARDA, 2000), in contrast to this, in this study seed color and row types were not obligatory.

Participatory barley variety selection in Eritrea showed farmers' preferences for grain filling, spike length and in some cases tall plants and in Bale it is similar for grain filling; whereas, grain yield and biomass was highly correlated with breeders' selection (ICARDA, 1999) in Eritrea.

This study reveals that breeders' selection criteria were mainly grain yield, early maturity and disease resistance during the two phases of this research work. Insect resistance was one of an important criterion during 2007 Bona season. This is in agreement with ICARDA report (1998) on barley which was carried out in Morocco at Merchouch and Jemma Shahim area except for insect resistance. On top of this, another PBB 


\section{Zerihun, Amsalu \& Grando}

which was conducted in Syria indicate farmers and breeders' preference for large kernels and higher grain yield (Ceccarrelli et al., 2000), which was similar to this findings. Some specific selection criteria such as thresh ability, less husk content, number of kernels per spike and bending nature of the spike have been also considered by some farmers at some sites as important criteria during this study which makes different from other findings. The reason of coincidence of farmers and breeders selection criteria in this study could be most of the barley experiments have been conducted on farmers' fields in Bale and the presence of large state farms in these areas also could have increased farmers' interaction with researchers or experts so that they had better concept on variety selection and selection of important traits like disease resistance. Most of the above mentioned varieties (Figure 2) were developed by Sinana Agricultural Research Center barley breeding program from local landrace collections and recommended for commercial production in Bale highlands. And, these varieties showed specific adaptation to these areas. In general, some of good characteristics of these varieties include early maturity, highly shoot fly resistant or tolerant, better disease resistance, high yielder and stable. At Upper Dinsho (Hora Soba site), late maturing varieties such as Shage, Dimtu, $27^{\text {th }}$ IBON 73/99 (advanced line) and Meserach were selected by farmers in group as well as individually as top performing varieties and their performance revealed specifically well adapted to this environment. These varieties give high yield at higher altitudes (cool environments) where there is relatively no or very minimum shoot fly incidence. On the other hand, breeders' selection of varieties was also similar to farmers. Therefore, farmers as well as breeders were able to select high yielding varieties. Similar result was reported by Ceccarrelli et al. (2000) and Ceccarrelli et al. (2003) in their study in Syria. In this study, farmers variety selection tended to vary more from site to site which indicates that farmers are trying to diverse their choices of varieties may be based on their specific needs and environmental conditions. This is one benefit of PPB in increasing crop biodiversity as described by Ceccarrelli and Grando (2007). Participatory variety selection enhances farmers' access to varieties (improved or local). The best and most suitable materials can be disseminated quickly through the informal seed system (Witcombe and Joshi, 1996; de Boef and Ogliari, 2008).

Upper Dinsho is a very cool specific environment in which biophysical factors differ
Sci. Technol. Arts Res. J., April-June 2012, 1(2):01-11

significantly as compared to the rest selection sites. We have observed that the performance of barley varieties as well as farmers' selection of varieties at Upper Dinsho (Hora Soba site) is completely different from the other sites during evaluation. Barleys which performed well and selected repeatedly by the farmers at other evaluation sites showed poor performance at Hora Soba, none of them have been selected. However, late maturing varieties such as Shage, Dimtu, $27^{\text {th }}$ IBON 73/99 (advanced line) and Meserach variety have shown superior performance and well adapted to this environment. Therefore, these varieties are selected by the local farmers individually and/or in group because of their important merits. During selection, at Hora Soba farmers strictly compared varieties with their local cultivars such as Falibaye, Kasale, Limat \& Senefkolo. Senefkolo (semi-hulled), two rowed, local variety commonly grown for kolo (roasted barley). Hence, the condition at Upper Dinsho reveals the importance of specific breeding program for barley. Similarly, Fetien and Bjørnstad, (2008) indicated that farmer developed variety Himblil adapted to specifically adapted to low input and low rain fall areas of Tigray.

\section{CONCLUSIONS}

Farmers were effective in identifying most of the higher yielding varieties as breeders. Productive tillers and kernel size were selection criteria not frequently used by breeders, but used by farmers. Shoot fly insect resistance was specifically breeders' criteria during Bona cropping season due to the prevalence of this biological pest is severe during this season. Guta, Dinsho, Biftu and Harbu varieties were selected as the best variety preferred by most of the local farmers across sites except at Hora Soba (Upper Dinsho) so that attention should be given to scaling up/out of these varieties in these areas. Beside this, new candidate variety known as Aruso/EH956/F 2 -8H-6-4-SNRFBC99G003-21, which was developed through crossing, was recently released from Sinana Agricultural research center after approval by the national variety releasing committee in 2011 with a common name Abdane due to its superior agronomic performances and acceptance by the local farmers in Bale mid highlands. On the other hand, specifically at Upper Dinsho area, Shage, Dimtu, and $27^{\text {th }}$ IBON 73/99 (semidwarf advanced line) varieties showed excellent performance in this area showing varietal specific adaptation which signifies breeding for specific adaptation. Generally, encouraging results have been obtained from this research activity with 


\section{Zerihun, Amsalu \& Grando}

ICARDA in the highlands of Bale which helps to integrate farmers' indigenous knowledge in barley improvement, create experience sharing between breeders and farmers with potentials and the limitations of barley technologies in the eyes of users. The study indicates the need of modification of formal breeding program system at Sinana to develop varieties that suits farmers' needs to avoid adoption problems.

\section{ACKNOWLEDGMENT}

The authors would like to thank ICARDA for their financial support to conduct the research \& Oromia Agricultural Research Institute, Sinana Agricultural Research Center, for their provision of logistic support to carry out the experiment.

\section{REFERENCES}

Berhane, L., Hailu, G., Fekadu, A. (1996). Barley production and research. In: Gebre, H., Joop, V.L., (Eds.), Barley research in Ethiopia: Past Work and Future Prospects. In: Proceedings of the First Barley Research Review Workshop, 16-19 Oct. 1993, IAR/ICARDA, Addis Ababa, Ethiopia, Pp. 1-8.

Ceccarrelli, S., Grando, S., Tutwiler, R., Baha, J., Martini, A.M., Salahich, H., Goochild, A., Michael, M. (2000). A methodological study on participatory barley breeding I. Selection phase. Euphytica 111: 91-104.

Ceccarrelli, S., Grando, S., Sing, M., Michael, M., Shikho, A., Al Issa, M., Al Salch, A., Kalconjy, G., Al Ghanem, S.M., Al Hassan, A.L., Dalla, H., Bahsa, S., Basha, T. (2003). A methodological study on participatory barley breeding II. Response to selection. Euphytica 133:185-200.

Ceccarrelli, S., Grando, S. (2007). Decentralized participatory plant breeding: An example of demand driven research. Euphytica 155:349-360.

CSA (Central Statistical Authority). (2005). Federal Democratic Republic Ethiopia: Central statistics Authority, Agricultural Sample survey 2004/5 (1997E.C) (Sep 2004-Feb 2005) Vol. 1. Report on Area and Production of crops (private peasant holdings, Meher season) Statistical Bulletin No. 331. Addis Ababa, Pp.1-48.

EASE (Ethiopian Agricultural Sample Enumeration). (2002). Federal Democratic Republic Ethiopia: Central Agricultural census commission. Ethiopian Agricultural sample enumeration, 2001/02 (1994 E.C). Report on the preliminary results of area, Production and yield of temporary crops (Meher season, private peasant holdings), Part I. p.88.

Hailu, G., Berhane, L., Fekadu, F., Berhanu, B., Alemayehu, A., Tesfaye, G. (1996). Food barley breeding. In: Gebre, H., Joop, V.L. (Eds.), Barley research in Ethiopia: Past Work and Future Prospects. Proceedings of the First Barley Research
Sci. Technol. Arts Res. J., April-June 2012, 1(2):01-11

Review Workshop, 16-19 Oct. 1993, IAR/ICARDA, Addis Ababa, Ethiopia, Pp.9-23.

Fetien, A., Bjørnstad, A. (2008). Participatory varieties selection of barley in the highlands of Tigray in Northern Ethiopia. In: Thijssen, M.H., Bishaw, Z., Beshir, A. de Boef, W.S. (Eds.), Farmers, seeds and varieties: supporting informal seed supply in Ethiopia. Wageningen International. Pp.198-206.

Harlan, J.R. (1976). Barleys. In: Simmonds. N.W. (Eds.), Evolution of Crop Plants, University of Illinois Urbana, USA, Longman Inc. New York, Pp.93-98.

ICARDA. (1998). Annual Report .Farmers participatory barley breeding in Tunisia and Morocco. The International Center for Agricultural Research in the Dry Areas (ICARDA) Aleppo, Syria, Pp.32-34.

ICARDA. (1999). Report on Participatory barley breeding in Eritrea .http:www.icarda.cgiar.org/ farmer _participation/PDF/Reports/Eritrea99.pdf.

ICARDA. (2000). Annual Report on Germplasm Program: The International Center for Agricultural Research in the Dry Areas (ICARDA) Aleppo, Syria, Pp.67-97.

ICARDA. (2002). ICARDA and Ethiopia: Ties that bind, Issue No. 16, ICARDA, Aleppo, Syria, Pp: 1-16.

Kling, J.G., Hayes, P.M. (2004). Barley Genetics and Breeding. In: Wrigley, C., Corke, H., Walker H. (Eds.), Encyclopedia of Grain Science, Pp.27-37.

Morris, M.L., Bellon, M.R. (2004). Participatory plant breeding research: Opportunities and challenges for the international crop improvement system. Euphytica 136:21-35.

Onwuemen, I.C., Singh, T.S. (1991). Field Crop Production in Tropical Africa, CTA, Wageningen, The Netherlands, Pp.225-232.

SPSS (Statistical Package for Social Science), (2003). Statistical Package for Social Science program 12.0 version, Cary, North Carolina., USA.

Voss, J. (1996). Participatory breeding and IDRC's biodiversity program. In: Eyzaguirre, P., Iwanaga M.(Eds.), Proceedings of a workshop on participatory plant breeding, 25-29 July 1995, Wageningen, The Netherlands, IPGR, Rome, Italy. Pp.3-8.

De Boef, W.S., Ogliari, J.B. ( 2008). Participatory crop improvement and supporting informal seed supply. In: Thijssen, M.H., Bishaw, Z., Beshir, A. de Boef, W.S. (Eds.), Farmers, seeds and varieties: supporting informal seed supply in Ethiopia. Wageningen, Wageningen International. Pp.177185.

Witcombe, J., Joshi, A. (1996). Farmers participatory approaches for varietal breeding and selection and linkages to the formal seed sector. In: Eyzaguirre, P., Iwanaga, M. (eds.), Proceedings of a workshop on participatory plant breeding, 25-29 July 1995, Wageningen, the Netherlands, IPGR, Rome, Italy, Pp. 57-65. 